\title{
Bioaccumulation of heavy metals in Oreochromis niloticus (Linn. I 758) of Agodi Reservoir, Ibadan, Nigeria
}

\begin{abstract}
The concentration of $\mathrm{Cd}, \mathrm{Co}, \mathrm{Cu}, \mathrm{Fe}, \mathrm{Mn}, \mathrm{Ni}, \mathrm{Pb}$, and $\mathrm{Zn}$ in Oreochromis niloticus (generally called Tilapia fish) was assessed at three different locations along Agodi Reservoir in Ibadan. Their relative concentrations were determined using Atomic Absorption Spectrophotometer (AAS). Test location differences and seasonal variations of the values were examined using statistical analysis of variance at $\mathrm{P}<0.05$ to establish pollution dynamics. The results showed declining order of heavy metal concentrations in the order of $\mathrm{Mn}>\mathrm{Fe}>\mathrm{Zn}>\mathrm{Cu}>\mathrm{Co}>\mathrm{Cd}>\mathrm{Pb}>\mathrm{Ni}$. Gradient effect was indicated. While $\mathrm{Cd}$ was found in decreasing order of concentration from inlet to the outlet, other metals like $\mathrm{Co}, \mathrm{Cu}$, $\mathrm{Fe}, \mathrm{Mn}, \mathrm{Ni}, \mathrm{Pb}$, and $\mathrm{Zn}$ had concentrations that gradually increased from inlet to the outlet. The concentration of $\mathrm{Cd}, \mathrm{Co}, \mathrm{Cu}, \mathrm{Pb}$, and $\mathrm{Zn}$ did not change considerably with season unlike $\mathrm{Fe}, \mathrm{Mn}$, and $\mathrm{Ni}$ that exhibited substantial seasonal variation. It was concluded that heavy metal accumulation caused marked pollution dynamics inside the Agodi Reservoir. Also, bio-accumulation of the metals in Oreochromis niloticus could give birth to location and seasonal dependency.
\end{abstract}

Keywords: Agodi Reservoir, Oreochromis niloticus, heavy metal, bioaccumulation, gradient effect
Volume 6 Issue 2 - 202I

\author{
Ogungbile PO,' JA Akande,' AO Adepoju, ${ }^{2}$ \\ TO Ogunbode,' MKC Sridhar ${ }^{3}$ \\ I Environmental Management Unit, College of Agriculture, \\ Engineering and Science, Bowen University, Nigeria \\ 2Department of Biological Sciences, Fourah Bay College, \\ University of Sierra Leone, Nigeria \\ ${ }^{3}$ Department of Environmental Health Sciences, Faculty of \\ Public Health, College of Medicine, University of Ibadan, Nigeria
}

Correspondence: Ogungbile PO, Environmental Management Unit, College of Agriculture, Engineering and Science, Bowen University, P.M.B 284, Iwo-Osun State, Nigeria,

Tel 234-8037708479, Email ogungbilepeter@yahoo.com

Received: February 23, 202I | Published: March 25, 202 I

\section{Introduction}

Fishes are vertebrate animals with gills that live inside water Freshwater fishes are those that spend their lives in freshwater like rivers, lakes, and reservoirs with low salinity of less than $1.05 \%{ }^{1}$ Fish is a salient asset for humans, especially as food, commercial, or livelihood, and has had a role in the way of life through the ages serving as the supreme being and the subject of art, books, and movies. ${ }^{2}$ According to Picker and Griffiths, ${ }^{3}$ fish are consumed as food virtually in all parts of the world. They are a significant source of protein and other nutrients for humans. Fishes are important in the aquatic food chain, sensitive to pollutants that can either be organic or inorganic including heavy metals (such as $\mathrm{Hg}, \mathrm{Pb}, \mathrm{As}, \mathrm{Cd}, \mathrm{Cr}$, and $\mathrm{Cu}$ ). Heavy metals are so characterized as having molecular weights heavier than water at $18 \mathrm{~g} / \mathrm{mol}$. Heavy metals find their way into water bodies from concentrated wastewater, sewage, industrial activities, and mining operations. ${ }^{4}$ They contaminate soil systems, water sources, and humans exposed to heavy metals through food consumption. Some metals are poisonous to humans even in small concentrations.

In every ecosystem, organisms are intricately interconnected through food chains and food webs. When heavy metals find their way into an organism, they can build up and linger on a phenomenon called bioaccumulation. Michael et al., ${ }^{5}$ defined bioaccumulation as a process in which a chemical pollutant enters into an organism and is not excreted, but accumulated in the tissues. The two main causes of bioaccumulation are the amount of the chemicals coming into the living organism faster than the living organism can assimilate and the build-up of contaminants such as heavy metals or pesticides in living organisms. ${ }^{6}$ Aquatic organisms are often subject to bioaccumulation because they absorb contaminants from the water faster than their bodies can excrete them. Humans are also subject to bioaccumulation, either from consuming contaminated aquatic organisms or from exposure to contaminants either in food, air, or water. Heavy metals do not biodegrade, which means they can last for a long time in the system. ${ }^{7}$ Heavy metals could bind to the surface of microorganisms including phytoplankton in oceans and sometimes enter the cells. Once they enter into the cells, heavy metals can react with chemicals released by microorganisms to digest food and undergo chemical transformations Elley et al. ${ }^{8}$ In this process, heavy metals bioaccumulate in the bodies of living organisms, and by the time they are assimilated, they can constitute health effects in the human body.

There are many reported studies on the bioaccumulation of heavy metals in fish. Elley et al. ${ }^{8}$ assessed heavy metals in water, sediment, and fish tissues from Sharkia province in Egypt. Their study revealed that the muscles, gills, kidney, and liver tissues of fish samples collected from industrial drainage and sewage canals had the highest level of heavy metal residues followed by agriculture drainage canals. Similarly, Elley et al. ${ }^{8}$ carried out studies of bioaccumulation of some heavy metals in fish samples from River Benue in Vinikilang, Adamawa State, Nigeria. They observed differences in trace metal concentrations between different tissues within the fishes. The level of metals bioaccumulated in tissues of Tilapia zilli amd Clarias angullaris differ. The highest level of all the metals was observed in the gills and liver of the four fish samples while their flesh showed the lowest values. Fabio et al. ${ }^{9}$ investigated the concentrations of mercury $(\mathrm{Hg})$, cadmium $(\mathrm{Cd})$, zinc $(\mathrm{Zn})$, chromium $(\mathrm{Cr})$, and lead $(\mathrm{Pb})$ in muscle, liver, and spleen tissues of Pesdoplatystoma corruscans specimen collected from two sites on the Paraopeba River, Brazil. The results of their findings indicate that the level of heavy metal concentrations in the tissues was often higher in viscera (i.e. liver and spleen) than in muscle, and thus the viscera should not be considered for human consumption. 
The differences that occur among the various heavy metals in the fishes are compounding. Primarily it could be due to variation in the concentration of contaminant in the water bodies..$^{10}$ Olgunoglu et al. ${ }^{11}$ reported that heavy metal accumulation is influenced by external factors including dissolved metals physicochemistry, dissolved oxygen, interactions between metals, sediment, food, seasonal effects, geographical differences, and internal (individual variability, body size and development stage, sex, breeding condition, brooding, molding and growth, behavior), physicochemical properties of the contaminants, its distribution pattern in the aquatic ecosystem, the feeding mode, lipid content in the tissue and the metabolism of the aquatic organism. ${ }^{12}$ Also according to the literature bioaccumulation by fish and subsequent distribution in organs is inter-specific by the type of tissue/organ, age, size of fish, exposure period, mechanisms of uptake, intrinsic factors, and environmental conditions of the habitat of fisheries. ${ }^{12,13}$

Heavy metals have biological functions. Heavy metals are dangerous to life once the level exceeds the tolerable limit over a long period of exposure. ${ }^{10}$ Also, extremely low concentration could harm the organisms. Izah et al., ${ }^{10}$ evaluated the function of some essential heavy metals that are needed by human bodies. For example, iron has an important role as a constituent of enzymes, such as cytochromes and catalase, and oxygen-transporting proteins such as hemoglobin. ${ }^{10}$ The deficiency of iron could cause various types of diseases. ${ }^{14}$ Unfortunately, heavy metals do have serious health effects on humans. Many play a role in cancer development or cause internal organ damage even at low concentrations of $\mathrm{Cd}, \mathrm{Co}, \mathrm{Pb}, \mathrm{Ni}$, and $\mathrm{Hg}$ which are also known to affect the formation of blood cells and make the metals react to the surface of the cells, making them less elastic and therefore, less able to circulate throughout the body. ${ }^{15}$
The objective of this work is to study heavy metal pollution inside Agodi Reservoir, a man made water body that existed in Ibadan for several decades by evaluating the concentration of heavy metals in Oreochromis niloticus caught from three different locations in the reservoir.

\section{Materials and methods}

\section{Study area}

The study was carried on Agodi Reservoir located in Ibadan, Oyo State, Southern Nigeria. Ibadan is located on longitude $3^{\circ} 5^{\prime}$ East of Greenwich meridian and latitude $70^{\circ} 23^{\prime} \mathrm{N}$ west of the equator. Agodi reservoir was formed along Ogunpa River that flows into the reservoir. The reservoir has an area of 13 hectares stretching about $1 \mathrm{~km}$ with a maximum depth of about $5 \mathrm{~m}$. The river upstream is often polluted by deposited solid and liquid waste products resulting from anthropogenic activities. The sources of pollution are predominantly sewage, urban run-off, and agricultural effluents consisting of chemical fertilizers, pesticides, industrial sources associated with different types of chemical pollutants which are both organic and inorganic, containing heavy metals and microbial organisms. Agodi Reservoir is therefore subject to enormous anthropogenic stress that deteriorates the water quality and contaminates the aquatic system including the fishes (ref).

\section{Sampling sites}

The samples were collected for 12 months comprising of dry and wet seasons. They were cropped with the help of a cast net from three sampling locations identified as inlet $(F)$, center $(G)$, and outlet $(H)$ of the reservoir (Figure1).

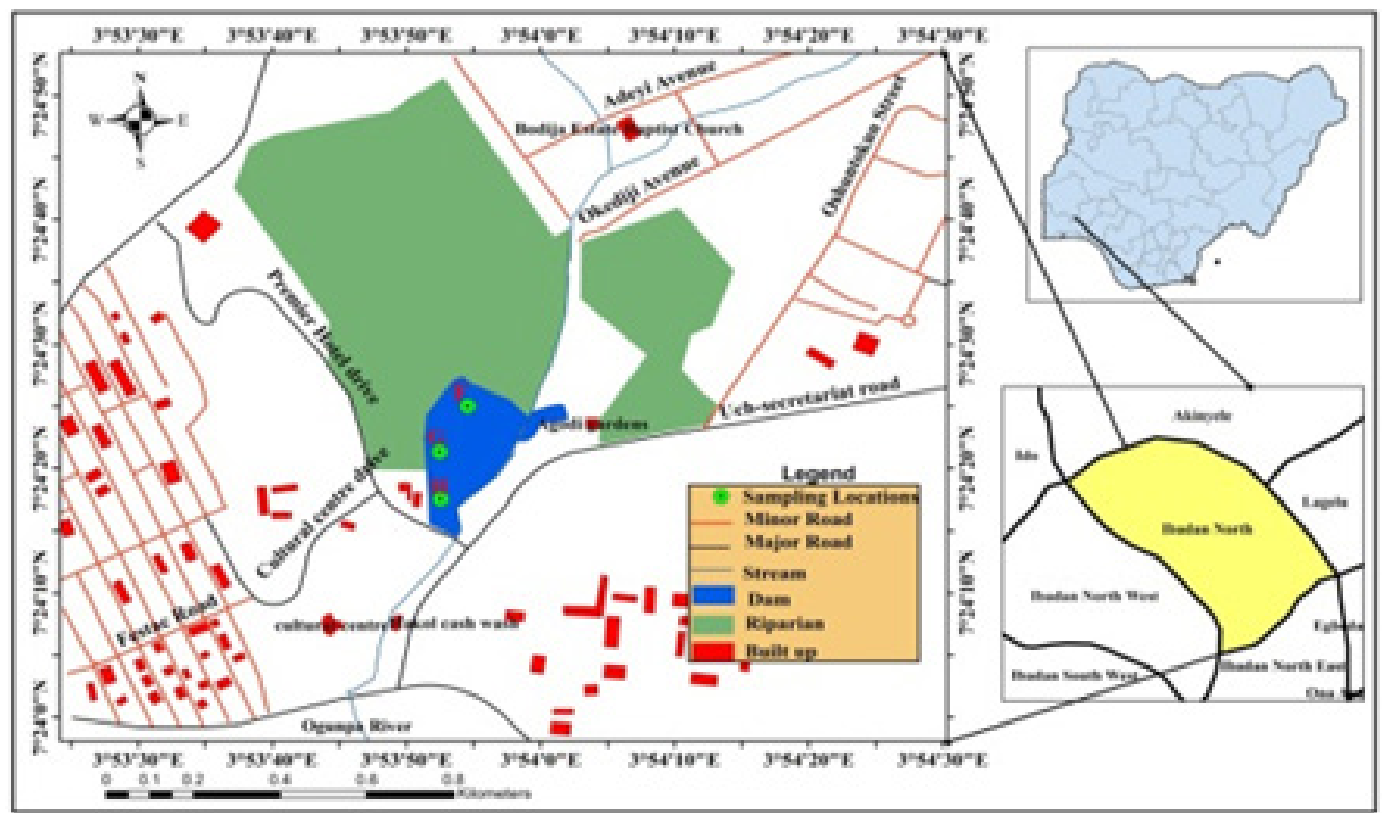

Figure I Sampling locations F, G, H in Agodi Reservoir.

\section{Material handling}

The fish samples were washed with distilled water and kept in the icebox and transferred to the laboratory for further treatment. In the laboratory, the fish were dried individually to constant weights kept in polythene bags after capturing and dried individually to constant weights in an oven set at $105^{\circ} \mathrm{C}$ according to AOAC. ${ }^{16}$ Thereafter, the dried samples were grounded into a fine powder with mortar and pestle, ready for digestion.

\section{Analytical procedures}

The digested fish samples were analyzed for $\mathrm{Cd}, \mathrm{Co}, \mathrm{Cu}, \mathrm{Fe}, \mathrm{Mn}$, $\mathrm{Ni}, \mathrm{Pb}$, and $\mathrm{Zn}$ using Atomic Absorption Spectrophotometer. The 
instrument setting and operational conditions were done following the manufacturers' (BUCK 200) specifications.

\section{Statistical analyses}

Data collected were subjected to one-way analysis of variance to determine significant differences in the heavy metal concentration found in the fishes at the sampling locations.

\section{Results}

\section{Concentrations of heavy metals in test fishes}

Table 1 presents heavy metal concentrations in the test fishes between the dry and wet seasons. The overall mean of the heavy metals in a calendar year of 12 months showed declining concentrations in this order $\mathrm{Mn}>\mathrm{Fe}>\mathrm{Zn}>\mathrm{Cu}>\mathrm{Co}>\mathrm{Cd}>\mathrm{Pb}>\mathrm{Ni}$.

Table I Dry and wet seasons variations of heavy metals in Oreochromis niloticus along Agodi Reservoir

\begin{tabular}{|c|c|c|c|c|c|c|c|c|c|c|}
\hline \multirow{3}{*}{ Heavy metals } & \multicolumn{10}{|c|}{ Agodi Reservoir } \\
\hline & \multicolumn{3}{|c|}{ Dry season } & \multirow{2}{*}{ Mean } & \multicolumn{3}{|c|}{ Wet season } & \multirow{2}{*}{ Mean } & \multirow{2}{*}{$\begin{array}{l}\text { Overall } \\
\text { mean }\end{array}$} & \multirow{2}{*}{$\begin{array}{l}\text { FAO } \\
\text { std }\end{array}$} \\
\hline & $\mathbf{F}$ & G & $\mathbf{H}$ & & $\mathbf{F}$ & $\mathbf{G}$ & $\mathbf{H}$ & & & \\
\hline $\mathrm{Cd}(\mathrm{mg} / \mathrm{kg})$ & 8.77 & 0.14 & 0.06 & 2.97 & 0 & 0.14 & 0.12 & 0.09 & 1.53 & 0.2 \\
\hline Co (mg/kg) & 0 & 0 & 11.06 & 3.69 & 0.22 & 1.22 & 1.68 & 1.04 & 2.37 & 5 \\
\hline $\mathrm{Cu}(\mathrm{mg} / \mathrm{kg})$ & 5.23 & 2.85 & 5.98 & 4.69 & 6.51 & 15.76 & 16.88 & 13.05 & 8.87 & 3 \\
\hline $\mathrm{Fe}(\mathrm{mg} / \mathrm{kg})$ & 0.63 & 0 & 0 & 0.21 & 102.44 & 511.38 & 1012,19 & 542 & 271.1 & 0.5 \\
\hline $\mathrm{Mn}(\mathrm{mg} / \mathrm{kg})$ & 75.19 & 64.13 & 48.69 & 62.67 & 53.88 & 609.79 & 966,66 & 543.44 & 303.06 & 0.5 \\
\hline $\mathrm{Ni}(\mathrm{mg} / \mathrm{kg})$ & 0 & 0 & $\mathrm{I} .44$ & 0.48 & 0.6 & 1.08 & 1.27 & 0.98 & 0.73 & 67.9 \\
\hline $\mathrm{Pb}(\mathrm{mg} / \mathrm{kg})$ & 0 & 0 & 0 & 0 & 0 & 0.29 & 6.04 & 2.11 & 1.06 & 2 \\
\hline Zn (mg/kg) & 187.05 & 82.07 & 95.07 & 121.4 & 174.15 & 223.37 & 312,24 & 236.59 & 179 & 30 \\
\hline
\end{tabular}

T-test statistic at $95 \%$ C.I. was employed to determine seasonal variations while regression curves were plotted to show indicative slopes, gradients effect, and correlation coefficients (Figures 2-9).

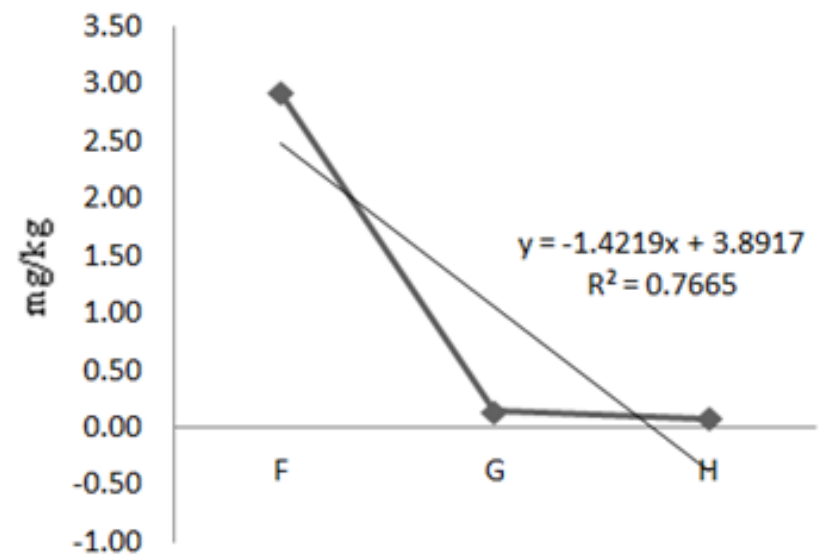

Figure 2 Concentration of $\mathrm{Cd}$ in Oreochromis niloticus along test locations $(F, G, H)$ in Agodi Reservoirs.

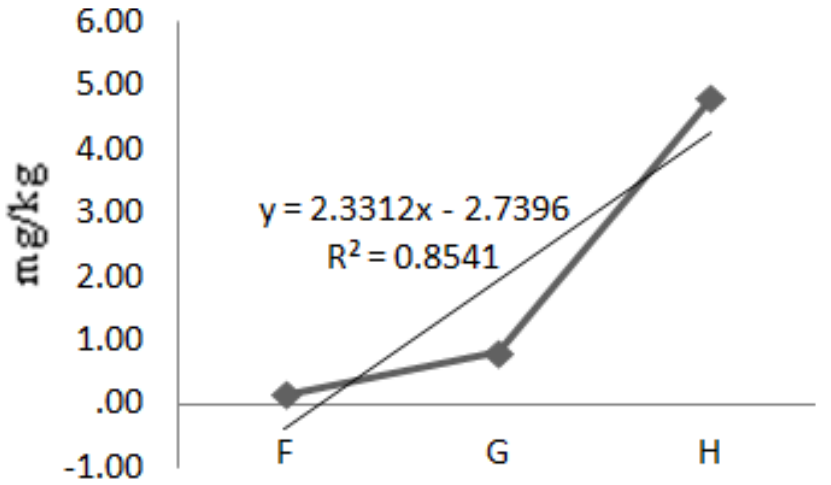

Figure 3 Concentration of $\mathrm{Co}$ in Oreochromis niloticusa long test $(\mathrm{F}, \mathrm{G}, \mathrm{H})$ in Agodi Reservoirs.

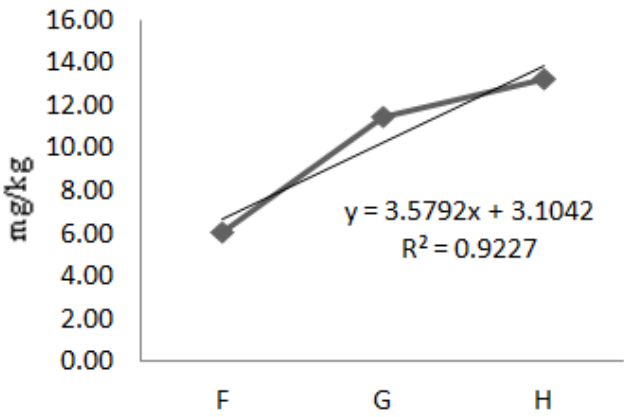

Figure 4 Concentration of $\mathrm{Cu}$ in Oreochromis niloticus along test locations $(\mathrm{F}, \mathrm{G}, \mathrm{H})$ in Agodi Reservoirs.

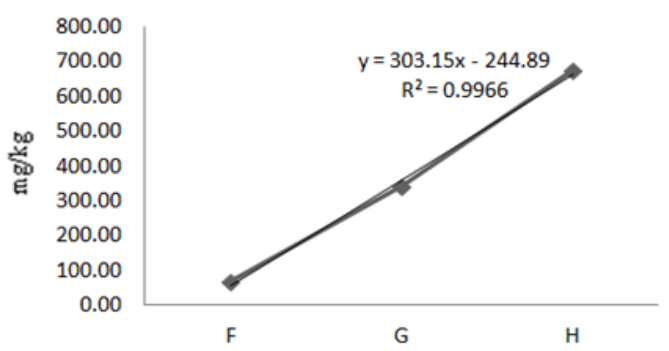

Figure 5 Concentration of $\mathrm{Fe}$ in Oreochromis niloticus along test locations $(\mathrm{F}, \mathrm{G}, \mathrm{H})$ in Agodi Reservoirs.

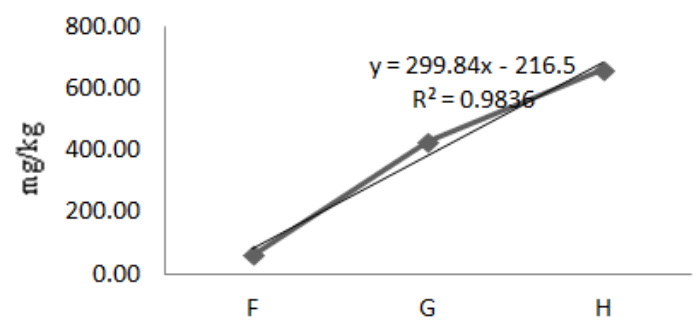

Figure 6 Concentration of $\mathrm{Mn}$ in Oreochromis niloticus along test locations $(F, G, H)$ in Agodi Reservoirs.

Citation: Ogungbile PO, Akande JA, Adepoju AO, et al. Bioaccumulation of heavy metals in Oreochromis niloticus (Linn. I 758) of Agodi Reservoir, Ibadan, Nigeria. MOJ Eco Environ Sci. 2021;6(2):35-4I.DOI: 10.15406/mojes.202I.06.002II 


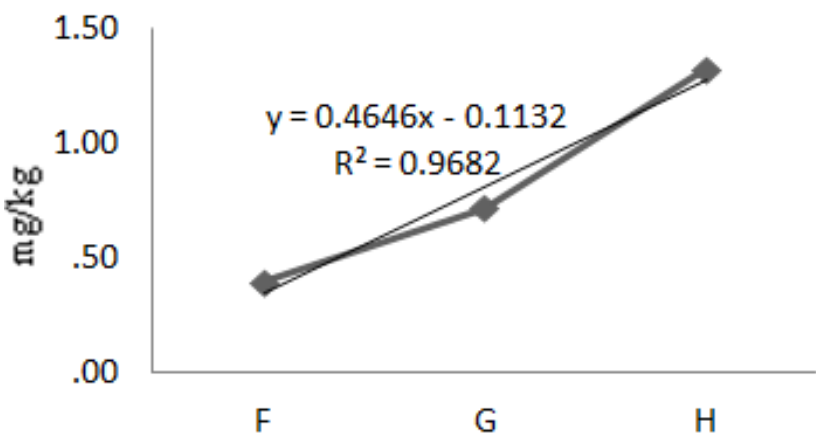

Figure 7 Concentration of $\mathrm{Ni}$ in Oreochromis niloticus along test locations $(\mathrm{F}, \mathrm{G}, \mathrm{H})$ in Agodi Reservoirs.

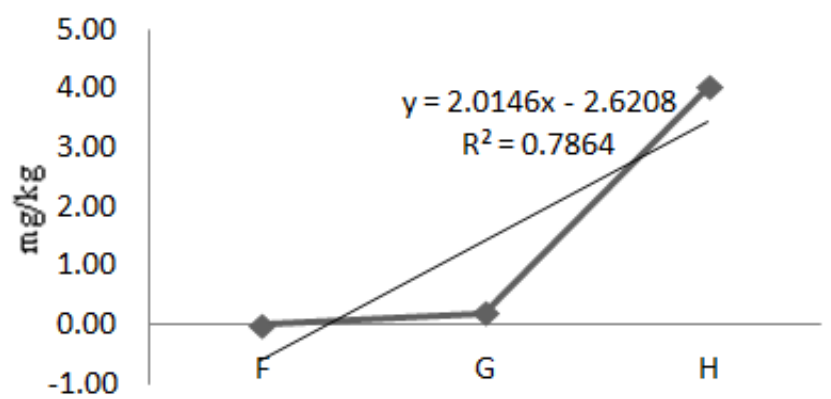

Figure 8 Concentration of $\mathrm{Pb}$ in Oreochromis niloticus along test locations $(\mathrm{F}, \mathrm{G}, \mathrm{H})$ in Agodi Reservoirs.

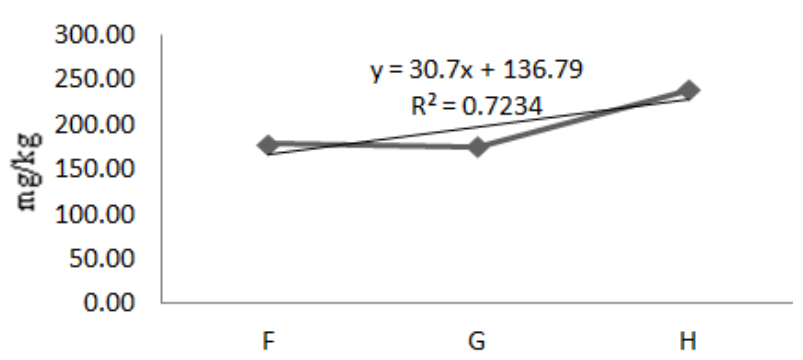

Figure 9 Concentration of $\mathrm{Zn}$ in Oreochromis niloticus along test locations $(\mathrm{F}, \mathrm{G}, \mathrm{H})$ in Agodi Reservoirs.

Interpretations of the curves are presented in Tables $2-4$ where the gradient, seasonal variations and two-tailed correlation coefficients between the heavy metal concentrations are respectively presented. The following explanations summarize the bio-accumulation patterns of each of the analyzed heavy metals in the captured fishes relative to their locations in the reservoir and the season of the year they were cropped.
Table 2 Gradient of heavy metal concentrations in Oreochromis niloticus with sampling locations in Agodi Reservoir

\begin{tabular}{|c|c|c|c|c|}
\hline Locations & $\mathbf{F}$ & G & $\mathbf{H}$ & r2 \\
\hline Metals & & & & \\
\hline $\mathrm{Cd}$ & 0 & & & $77 \%$ \\
\hline Co & 0 & & & $85 \%$ \\
\hline $\mathrm{Cu}$ & 0 & & & $92 \%$ \\
\hline $\mathrm{Fe}$ & 0 & & & $99.60 \%$ \\
\hline $\mathrm{Ni}$ & 0 & & & $97 \%$ \\
\hline$M n$ & 0 & & & $98 \%$ \\
\hline $\mathrm{Pb}$ & 0 & & & $77 \%$ \\
\hline $\mathrm{Zn}$ & C & & & $72 \%$ \\
\hline
\end{tabular}

$r^{2}$ is the correlation coefficient of the data

Table 3 Heavy metals analyses for gradient and seasonal variation for Oreochromis niloticus in Agodi Reservoir

\begin{tabular}{|c|c|c|c|c|}
\hline \multirow{3}{*}{$\begin{array}{l}\text { Reservoir } \\
\text { Heavy } \\
\text { metals }\end{array}$} & \multicolumn{3}{|c|}{$\begin{array}{l}\text { Gradient along test locations on } \\
\text { Agodi Reservoir ANOVA at } P<0.05\end{array}$} & \multirow{3}{*}{$\begin{array}{l}\text { Seasonal } \\
\text { variation } \\
\text { T-test } \\
\text { Statistic } \\
\text { at } \mathrm{P}<0.05 \\
\text { Fish F - H }\end{array}$} \\
\hline & Fish F - H & $r 2$ & $\mathrm{dy} / \mathrm{dx}$ & \\
\hline & \multicolumn{3}{|l|}{ \#Slope } & \\
\hline $\mathrm{Cd}$ & -ve & 0.77 & 1 & 0 \\
\hline Co & +ve & 0.85 & 1 & 0 \\
\hline $\mathrm{Cu}$ & $+v e$ & 0.92 & I & 0 \\
\hline $\mathrm{Fe}$ & +ve & I & I & 1 \\
\hline $\mathrm{Mn}$ & +ve & 0.98 & I & I \\
\hline $\mathrm{Ni}$ & +ve & 0.97 & I & 1 \\
\hline $\mathrm{Pb}$ & $+v e$ & 0.79 & 1 & 0 \\
\hline $\mathrm{Zn}$ & $+\mathrm{ve}$ & 0.72 & I & 0 \\
\hline
\end{tabular}

Note: For gradient $(\mathrm{dy} / \mathrm{dx})$ and seasonal variation (I) significant established $(0)=$ Not significantly established \#slope is slanting course from horizontal

Table 4 Two-tailed correlation coefficient between heavy metals in Oreochromis niloticus

\begin{tabular}{|c|c|c|c|c|c|c|c|c|c|}
\hline & $C d$ & Co & $\mathrm{Cr}$ & $\mathrm{Cu}$ & $\mathrm{Fe}$ & Mn & $\mathbf{N i}$ & $\mathbf{P b}$ & $Z_{n}$ \\
\hline & (mg/kg) & (mg/kg) & $(\mathrm{mg} / \mathrm{kg})$ & $(\mathrm{mg} / \mathrm{kg})$ & $(\mathrm{mg} / \mathrm{kg})$ & $(\mathrm{mg} / \mathrm{kg})$ & (mg/kg) & (mg/kg) & $(\mathrm{mg} / \mathrm{kg})$ \\
\hline $\begin{array}{l}\mathrm{Cd} \\
(\mathrm{mg} / \mathrm{kg})\end{array}$ & I & & & & & & & & \\
\hline $\begin{array}{l}\text { Co } \\
(\mathrm{mg} / \mathrm{kg})\end{array}$ & 0.046 & I & & & & & & & \\
\hline $\begin{array}{l}\mathrm{Cr} \\
(\mathrm{mg} / \mathrm{kg})\end{array}$ & 0.031 & 0.011 & I & & & & & & \\
\hline
\end{tabular}

Citation: Ogungbile PO,Akande JA,Adepoju AO, et al. Bioaccumulation of heavy metals in Oreochromis niloticus (Linn. I 758) of Agodi Reservoir, Ibadan, Nigeria. MOJ Eco Environ Sci. 2021;6(2):35-4I. DOI: 10.15406/mojes.2021.06.002I I 
Table Continued...

\begin{tabular}{|c|c|c|c|c|c|c|c|c|c|}
\hline & $C d$ & Co & $\mathrm{Cr}$ & $\mathrm{Cu}$ & $\mathbf{F e}$ & $M n$ & $\mathbf{N i}$ & $\mathbf{P b}$ & Zn \\
\hline & (mg/kg) & (mg/kg) & $(\mathrm{mg} / \mathrm{kg})$ & $(\mathrm{mg} / \mathrm{kg})$ & (mg/kg) & (mg/kg) & (mg/kg) & (mg/kg) & (mg/kg) \\
\hline $\begin{array}{l}\mathrm{Cu} \\
(\mathrm{mg} / \mathrm{kg})\end{array}$ & 0.085 & 0.09 & 0.258 & I & & & & & \\
\hline $\begin{array}{l}\mathrm{Fe} \\
(\mathrm{mg} / \mathrm{kg})\end{array}$ & 0.099 & 0.039 & 0.192 & $.35 I *$ & 1 & & & & \\
\hline $\begin{array}{l}\text { Mn } \\
(\mathrm{mg} / \mathrm{kg})\end{array}$ & 0.067 & 0.087 & $.46 I^{* *}$ & & & I & & & \\
\hline $\begin{array}{l}\mathrm{Ni} \\
(\mathrm{mg} / \mathrm{kg})\end{array}$ & 0.067 & $.426 * *$ & -0.065 & -0.103 & $.495^{* * *}$ & 0.132 & 1 & & \\
\hline $\begin{array}{l}\mathrm{Pb} \\
(\mathrm{mg} / \mathrm{kg})\end{array}$ & 0.012 & 0.045 & 0.006 & & $.382 *$ & $.480 * *$ & 0.015 & I & \\
\hline $\mathrm{Zn}(\mathrm{mg} / \mathrm{kg})$ & 0.055 & -0.052 & -0.081 & 0.098 & & & 0.322 & 0.122 & I \\
\hline
\end{tabular}

**Correlation is significant at 0.01 level (2-tailed)

*Correlation is significant at 0.05 level (2-tailed)

\section{Cd}

The mean concentration of Cadmium in Oreochromis niloticus samples captured during the experiment was $1.53 \mathrm{mg} / \mathrm{kg}$ (Table 1). Analysis of variance at $\mathrm{P}<0.05$ showed that the values were significantly different across the locations. A linear regression of $\mathrm{Cd}$ in Oreochromis niloticus along the sample locations showed a strong negative correlation of $77 \%$ (Eqn. 1, Figure 2). The mean value during the dry season was $2.97 \mathrm{mg} / \mathrm{kg}$ and the wet season was $0.09 \mathrm{mg} / \mathrm{kg}$ (Table 1). T-test statistic at $95 \%$ C.I. showed no seasonal variation (Table 3).

$$
C d: Y=-1.421 X+3.891
$$

Note: that in all equations 1 to 8 presented

$\mathrm{Y}=$ specific heavy metal measured in $\mathrm{mg} / \mathrm{kg}$ (dependent variable)

$\mathrm{X}=$ distance from source in meters (independent variable)

\section{Co}

The mean concentration of Co during the experimental year was $2.37 \mathrm{mg} / \mathrm{kg}$. Analysis of variance at $\mathrm{P}<0.05$ showed that the mean values did not differ across the locations, hence, no gradient effect. A linear regression of cobalt in Oreochromis niloticus along the sample locations revealed a strong positive correlation of $85 \%$ (Eqn. 2, Figure 3). The mean value of Cobalt in the dry season was $3.69 \mathrm{mg} / \mathrm{kg}$ and the mean value for the wet season was $1.04 \mathrm{mg} / \mathrm{kg}$. T-test statistic showed no significant seasonal variation (Table 3 ).

$$
\text { Co: } Y=2.331 X-2.739
$$

\section{$\mathrm{Cu}$}

The mean value at $\mathrm{Cu}$ in Oreochromis niloticus during the experimental year was $8.87 \mathrm{mg} / \mathrm{kg}$ (Table 1 ). The mean values were significantly different $(\mathrm{P}<0.05)$ from the reservoir inlet through the center to the outlet locations which signify the gradient effect. Linear regression of $\mathrm{Cu}$ in Oreochromis niloticus along the sample locations showed a strong positive correlation of $92 \%$ (Eqn.3, Figure 4). The mean values of the dry season and wet season were $4.69 \mathrm{mg} / \mathrm{kg}$ and $13.05 \mathrm{mg} / \mathrm{kg}$ respectively. T-test statistic at $95 \%$ C.I. showed that the values were not significantly different and thereby, suggested no seasonal variation (Table 3).

$$
C u: Y=3.579 X+3.104
$$

\section{$\mathrm{Fe}$}

The mean concentration of $\mathrm{Fe}$ during the experimental year was $271.10 \mathrm{mg} / \mathrm{kg}$ (Table 1). At $\mathrm{P}<0.05$, the analysis of variance of the means showed significant differences of iron in fishes at various locations. A linear regression line of iron in Oreochromis niloticus along the sample locations showed a strong positive gradient at a correlation of $99.9 \%$ (Eqn. 4, Figure 5). That means, as one move from location $\mathrm{F}$ to $\mathrm{G}$ to $\mathrm{H}$, there is a strong positive increment in $\mathrm{Fe}$ concentration. The concentration of Fe in the dry season was $0.21 \mathrm{mg} /$ $\mathrm{kg}$ and the concentration of $\mathrm{Fe}$ in the wet season was $542 \mathrm{mg} / \mathrm{kg}$. Iron varied with the seasons and the variations were statistically significant at $95 \%$ C.I. (Table 3).

$$
F e: Y=303.1 X-244.8
$$

\section{Mn}

The mean concentration of $\mathrm{Mn}$ in Oreochromis niloticus for the experimental year was $303.06 \mathrm{mg} / \mathrm{kg}$ (Table 1). The values differed significantly $(\mathrm{P}<0.05)$ across the sample locations which imply a gradient effect. A linear regression of $\mathrm{Mn}$ in Oreochromis niloticus along the sample locations revealed a strong correlation of $98 \%$ (Eqn. 5 , Figure 6). In other words, as one moves from location $F$ to $G$ to $\mathrm{H}$, there is a strong positive correlation that $\mathrm{Mn}$ will increase in the fish. The mean values of $\mathrm{Mn}$ in the fish for dry and wet seasons were $62.67 \mathrm{mg} / \mathrm{kg}$ and $543.44 \mathrm{mg} / \mathrm{kg}$ respectively (Table 3). Manganese varied with season and the variations were statistically significant.

$$
M n: Y=299.8 X-216.5
$$

\section{$\mathrm{Ni}$}

The mean concentration of Nickel in Oreochromis niloticus during the experimental year was $0.73 \mathrm{mg} / \mathrm{kg}$ (Table 1). At $\mathrm{P}<0.05$, the analysis of variance of the means showed significant differences in Nickel in fishes at various locations which imply a gradient effect. A 
linear regression line of $\mathrm{Ni}$ in Oreochromis niloticus along the sample locations revealed a positive correlation of $97 \%$ (Eqn. 6, Figure 7). The mean value of Nickel in the dry season and wet season were $0.48 \mathrm{mg} / \mathrm{kg}$ and $0.98 \mathrm{mg} / \mathrm{kg}$ respectively (Table 3). T-test statistic at $95 \%$ C.I. also showed significant seasonal variation as more solid wastes containing $\mathrm{Ni}$ were dropped in the river during the rainy season.

$$
N i: Y=0.464 X-0.113
$$

$\mathbf{P b}$

The mean concentration of $\mathrm{Pb}$ in Oreochromis niloticus during the test period was $1.06 \mathrm{mg} / \mathrm{kg}$ (Table 1). Analysis of variance of the means at $\mathrm{P}<0.05$ showed a significant difference in the locations. A linear regression of $\mathrm{Pb}$ in Oreochromis niloticus along the sample locations gave a positive correlation of $79 \%$ (Eqn. 7, Figure 8). Notably, $\mathrm{Pb}$ was not detected in Oreochromis niloticus during the dry season but $2.11 \mathrm{mg} / \mathrm{kg}$ was obtained in the wet season. T-test statistic at $95 \%$ C.I. showed no significant difference between the seasons which implied no seasonal variation (Table 3 ).

$$
P b: Y=2.014 X-2.620
$$

\section{Zn}

The mean concentration of $\mathrm{Zn}$ in Oreochromis niloticus during the test period was $179.00 \mathrm{mg} / \mathrm{kg}$ (Table 1). Analysis of variance of means along sample locations showed no significant difference which implies no gradient effect. A linear regression of $\mathrm{Zn}$ in Oreochromis niloticus is positive with a $72 \%$ correlation coefficient (Eqn.8, Figure 9). The mean value of $\mathrm{Zn}$ in Oreochromis niloticus during the dry season was $121.40 \mathrm{mg} / \mathrm{kg}$ while the wet season showed a value of $236.59 \mathrm{mg} / \mathrm{kg}$ T-test statistic at $95 \%$ C.I. showed no seasonal variation (Table 3 ).

$$
Z n: Y=30.7 X+136.7
$$

\section{The interrelationship between heavy metals in Oreochromis niloticus}

Two-tailed correlation coefficient (r) values for heavy metals in fish are presented in Table 4. Co concentration in Oreochromis niloticus is positively correlated with $\mathrm{Ni}$ at $\mathrm{P}<0.01$. A significant positive correlation also occurred between $\mathrm{Fe}$ and $\mathrm{Ni}$ at $\mathrm{P}<0.01$ but with $\mathrm{Pb}$ at $\mathrm{P}<0.05$. Mn concentration is positively correlated with $\mathrm{Pb}$ at $\mathrm{P}<0.01$.

\section{Discussion}

Biological essential heavy metals include $\mathrm{Cu}, \mathrm{Ni}, \mathrm{Fe}$, and $\mathrm{Zn}$. They are required by a wide variety of enzymes and other cell components also having a crucial role in all living organisms, but high concentrations can have unfavorable health effects. ${ }^{17,18}$ Non-biologically essential heavy metals include $\mathrm{Pb}$ and $\mathrm{Cd}$. They have no biological function and hence are dangerous to live organisms even at low levels, but become toxic as well at higher concentrations. ${ }^{19}$ In this study, the heavy metals concentrations in the fish Oreochromis niloticus were recorded in the following order $\mathrm{Mn}>\mathrm{Fe}>\mathrm{Zn}>\mathrm{Cu}>\mathrm{Co}>\mathrm{Cd}>\mathrm{Pb}>\mathrm{Ni}$ with concentrations of essential elements higher than non-essential except for Ni. These consequences may confirm the essential role of the former to fish species. ${ }^{17}$

In the present study, the concentrations $(\mathrm{mg} / \mathrm{kg})$ of heavy metals in for $\mathrm{Cd}$ (1.53), $\mathrm{Cu}$ (8.87), $\mathrm{Fe}$ (271.10), $\mathrm{Mn}$ (303.06), and $\mathrm{Zn}$ (179.00) were higher than the permissible limits of $\mathrm{Cd}(0.20), \mathrm{Cu}(3.00), \mathrm{Fe}$ (0.500), Mn (0.500) and $\mathrm{Zn}$ (30.00) for fish (FAO, 2007), while concentrations of $\mathrm{Co}$ (2.37), $\mathrm{Ni}(0.73), \mathrm{Pb}(1.06)$ were below FAO (2007) permissible limits of $\mathrm{Co}$ (5.00), $\mathrm{Ni}$ (67.90) and $\mathrm{Pb}$ (2.00).
In O. niloticus, $\mathrm{Cd}, \mathrm{Co}, \mathrm{Ni}$ and $\mathrm{Pb}$ were within $0-100 \mathrm{mg} / \mathrm{kg}$ range, $\mathrm{Cu}$ between $0-20 \mathrm{mg} / \mathrm{kg}$ while $\mathrm{Fe}, \mathrm{Zn}$, and $\mathrm{Mn}$ could be $700 \mathrm{mg} / \mathrm{kg}$ maximum (Table 1). These results demonstrate that apart from $\mathrm{Fe}$, $\mathrm{Mn}$, and sometimes $\mathrm{Zn}$ which have their concentrations greater than $100 \mathrm{mg} / \mathrm{kg}, \mathrm{Co}, \mathrm{Cu}, \mathrm{Cd}, \mathrm{N}$, and $\mathrm{Pb}$ were present in smaller quantities. T-test statistics for the heavy metals in O. niloticus variation of Fe, Mn, and $\mathrm{Ni}$ were established from wet to dry season through the reservoir, $\mathrm{Cd}, \mathrm{Co}, \mathrm{Cu}, \mathrm{Pb}$, and $\mathrm{Zn}$ showed no significant difference in the two seasons (Table 2). Generally, the concentrations of heavy metals in fish were higher during the wet season (Table 1). The concentration of $\mathrm{Cu}, \mathrm{Fe}, \mathrm{Mn}, \mathrm{Ni}, \mathrm{Pb}$, and $\mathrm{Zn}$ were higher in the wet season than in the dry season. These results were following those obtained by Saddi ${ }^{20}$ who found that heavy metals concentration showed seasonal variations, being greater in winter and lower in summer. This could be due to run-offs. This may further be attributed to the phytoplankton growth which was higher in summer and can absorb large quantities of heavy metals from water.

The results of heavy metals analyses in Oreochromis niloticus in the reservoir from the inlet to the outlet as shown in Figures 1-8 and Table 2 revealed that gradient existed in fishes obtained from Agodi Reservoir. Cadmium was found in decreasing order of concentration from the inlet to the outlet sources (Figure 1) (Table 2). The concentrations of $\mathrm{Co}, \mathrm{Cu}, \mathrm{Fe}, \mathrm{Mn}, \mathrm{Ni}, \mathrm{Pb}$, and $\mathrm{Zn}$ were found to be significant concentrations that increased from the reservoir inlet to the outlet (Figures 2-8) (Table 2).

Relatively high $\mathrm{r}^{2}$ values above $70 \%$ were obtained (Table 2$)$. The correlation powers of $\mathrm{Co}\left(\mathrm{r}^{2}=8.5 \%\right), \mathrm{Cu}\left(\mathrm{r}^{2}=92 \%\right), \mathrm{Fe}\left(\mathrm{r}^{2}=99 \%\right), \mathrm{Ni}$ $\left(\mathrm{r}^{2}=97 \%\right), \mathrm{Mn}\left(\mathrm{r}^{2}=98 \%\right), \mathrm{Pb}\left(\mathrm{r}^{2}=79 \%\right)$ and $\mathrm{Zn}\left(\mathrm{r}^{2}=72 \%\right)$ were strong enough to establish the positive gradient effect from the inlet to the outlet sources of the reservoir. The visible exception was $\mathrm{Cd}$ that attenuated from the inlet $\mathrm{F}$ to the center $\mathrm{G}$ and $\mathrm{H}$ outlet part of the reservoir. The deductible gradient effect in the reservoir may be attributed to the compelling gravitational or centrifugal accumulation of heavy metals as the water flow rate slowed down in the reservoir. Heavy metals discharged into the water body may accumulate in the body of the fish and not be excreted. ${ }^{21-23}$

\section{Conclusion}

Heavy metal concentrations in Oreochromis niloticus in Agodi Reservoir showed that all the heavy metals bioaccumulated in the fish. There were significant variations in $\mathrm{Fe}, \mathrm{Mn}$, and $\mathrm{Ni}$ loadings between the wet and dry seasons. In general higher concentrations of heavy metals were recorded in the wet season for $\mathrm{Cu}, \mathrm{Fe}, \mathrm{Mn}, \mathrm{Ni}, \mathrm{Pb}$, and $\mathrm{Zn}$ than in the dry season. This may be due to increased metal pollutants into the aquatic ecosystem during the wet season. However, the heavy metal concentrations in fish $\mathrm{Cd}$ and $\mathrm{Co}$ in the dry season were higher than in the wet season.

Heavy metal concentrations in sampled fish increased from the inlet to the outlet except for $\mathrm{Cd}$. The results of the linear regression of heavy metal concentration revealed that a gradient effect existed in the fishes obtained from Agodi Reservoir.. Heavy metals are important pollutants to the fish because they cannot be eliminated from the aquatic ecosystem by natural methods. The presence of $\mathrm{Cd}$ and $\mathrm{Pb}$ in the fish is a serious matter of concern which may expose human beings to the heavy metals from consuming fishes obtained from the reservoir.

\section{Acknowledgments}

None. 


\section{Funding}

None.

\section{Conflicts of interest}

The authors declare that there is no conflict of interest.

\section{References}

1. Griffins JD, Kennard MJ, Leprieur F, et al. Conservation biogeography of freshwater fishes: Recent progress and future challenges. Diversity and Distribution. 2016;16(3):496-513.

2. Abubakar A, Uzairu A, Ekwumemgbo PA, et al. Risk assessment of heavy metals in imported frozen fish Scomber scombrus species sold in Nigeria: A case study in zaria metropolis. Advances in Toxicology. 2015.

3. Picker MD, Griffiths CL. Alien and invasive animals - A South African perspective, randomhouse/struik, Cape Town South Africa 2016. 240 p.

4. Rao TP, Metilda J, Gladis M. Overview of analytical methodologies for sea water analysis: Part I-Metals. Critical Reviews in Analytical Chemistry. 2015;35:247-288.

5. Micheal K, Grandjean P, Dakeishi M. Neurophysiological evidence of methylmercury neurotoxicity. Am J Ind Med. 2017;50:765-771.

6. Ilyin I, Ryaboshapko A, Afinigenova O, et al. Lead, cadmium, and mercury transboundary pollution in 2000. MSC-E/CCC Technical Report; 2016.

7. William KO, Rose KA. Patterns of life-history diversification in North American fishes: Implications for population regulation. Canadian Journal of Fisheries and Aquatic Science. 2015;49(10):2196-2218.

8. Elley A El-Sayed, Mohammed S El-Sayed, El-Sayed Masr, et al Assessment of heavy metals in water, sediment, and fish tissues, from Sharkia province, Egypt. Egyptian Journal of Aquatic Biology and Fish. 2015;15(2):125-144

9. Fabio PArantes, Lourenco A Savassi, Helio B Santos, et al. Bioaccumulation of mercury, cadmium, chromium, and lead in muscle, liver, and spleen tissues of a large commercially valuable catfish species from Brazil. Annals of the Brazilian Academy of Sciences. 2016;88(1):137-147.

10. Izah SC, Chukrabarty N, Srivastav AL, A review on heavy metal concentration in potable water sources in Nigeria: Human health effects and mitigating measures. Exposure and Health. 2016;8(2):285-304.

11. Olgunoglu MP, Artar E, Olgunoglu IA. Comparison of heavy metal levels in muscle and gills of four bentic fish species f;rom the Northeastern Mediterranean Sea. Polish Journal of Environmental Studies. 2015;24(4):1743-1748.
12. Aghoghovwia OA, Ohimain EL, Izah SC. Bioaccumulation of heavy metals in different tissues of some commercially important fish species from Warri River Niger Delta, Nigeria Biotechnology Research. 2016;2(1):25-32.

13. Perera PACT, Suranga PACT, Kodithwakku P, et al. Bioaccumulation of cadmium in freshwater fish: An environmental perspective. Insight Ecology. 2015;4:1-12.

14. Adesuyi AA, Njoku KL, Akinola MO. Assessment of heavy metals pollution in soils and vegetation around selected industries in Lagos State Nigeria Journal of Geoscience and Environment Protection. 2015;3:1119.

15. Vasten H, Costa-Cabral M, Hagner C, et al. Four decades of gasoline lead emissions and control policies in Europe: a retrospective assessment. The Science of the Total Environment. 2017;311:151-176.

16. Association of Official Chemists AOAC. Official methods of analysis of AOAC. In: Gaithersburg MD, editor. 18th edn. Virginia, USA: Arlington; $2011.19 \mathrm{p}$

17. Obot OI, Isangedighi AI, David GS. Heavy metals concentration in some commercial fishes in the lower cross river estuary, Nigeria. Nigerian Journal of Agriculture, Food and Environment. 2016;12(4):218-223.

18. Behnam AL, Mansour GSN. Heavy metals in contaminated environment: Destiny of secondary metabolite biosynthesis, oxidative status on phytoextraction in medicinal plants. Ecotoxicology and Environmental Safety. 2017;145:377-390.

19. Hazrat Ali, Ezzat Khan. Bioaccumulation of non-essential hazardous heavy metals and metalloids in freshwater fish. Risk to human health. Environmental Chemistry Letters. 2018;16:903-917.

20. Saddiq SM. A study in factors affecting fish production from certain fish farms in the Delta. M.Sc. Thesis, Faculty of Science, Egypt: Amshoms University; 2015.

21. Food and Agricultural Organisation. Fishery profile. The Federal Republic of Nigeria; 2007. $24 \mathrm{p}$.

22. Pacy EG, Pacyna JM, Pirrone N. European emissions of atmospheric mercury from anthropogenic sources in 1995. Atmospheric Environment. 2016;35:2987-2996.

23. Sylvester Chibueze Izah, Tariwari CN Angaye. Heavy metal concentration in fishes from surface water in Nigeria. Potential sources of pollutants and mitigation measures. Sky Journal of Biochemistry Research. 2016;5(4):031-047. 